\title{
Wyoming big sagebrush control with metsulfuron and 2,4-D in northern New Mexico
}

\author{
KIRK C. MCDANIEL, DAVID L. ANDERSON, AND JOHN F. BALLIETTE
}

\section{Abstract}

Field experiments conducted between 1982 to 1988 compared 2,4-D [(2,4-dichlorophenoxy)acetic acid] and metsulfuron [2[I[[(4-methoxy-6-methyl-1,3,5-triazin-2-yl) amino]carbonyl]aminoksulfonyl]benzoic acid] for control of Wyoming big sagebrush (Artemisia tridentata ssp. wyomingensis Beetle and Young) in northern New Mexico. Precipitation was near or above normal during years of herbicide applications. Broadcast sprays of 2,4-D at $2.2 \mathrm{~kg} / \mathrm{ha}$ were most efficacious during rapid shoot elongation, but mortality averaged less than $38 \%$ from treatments applied over 4 separate years. Wyoming big sagebrush shoot growth was greatest in April and May compared to other months, but growth was highly variable among shrubs and probably reduced effectiveness of 2,4-D sprays. The optimum application timing for metsulfuron was during the late-flower growth and fruiting stages. Fall-applied metsulfuron at $0.035 \mathrm{~kg} / \mathrm{ha}$ provided $65 \%$ Wyoming big sagebrush mortality compared to $27 \%$ when spring-applied. When metsulfuron was fall-applied at $0.07 \mathrm{~kg} / \mathrm{ha}$ or higher, control averaged $88 \%$ following 3 annual applications. Combining metsulfuron at $.0175 \mathrm{~kg} / \mathrm{ha}$ plus $2,4-\mathrm{D}$ at $1.1 \mathrm{~kg} / \mathrm{ha}$ was comparable to or more effective than either herbicide applied alone in spring or fall. Total standing crop of grasses increased by nearly $300 \%$ after 1 or 2 growing seasons when Wyoming big sagebrush canopy cover was reduced by at least $75 \%$ following herbicide treatments.

Key Words: Artemisia tridentata ssp. wyomingensis, herbicides, herbage production, rangeland brush control

Herbicidal control of big sagebrush (Artemisia tridentata Nutt.) has been a common practice since the early 1950's in the intermountain region, and on the high plains of Wyoming, Montana, and the Dakotas (Evans et al. 1979). However, this practice has not been widely employed in the Colorado Plateau region (McDaniel and Balliette 1986). Control of big sagebrush with phenoxy herbicides, especially $2,4-\mathrm{D}$ at $2.2 \mathrm{~kg}$ ae/ ha, has been widely reported (Elwell and Cox 1950, Hormay et al. 1962, Hull and Vaughn 1951, Hyder and Sneva 1962, Evans et al. 1979, Vallentine 1980). Research and commercial experience has shown big sagebrush is easily controlled when phenoxy herbicides are applied in late spring-early summer during the period of active leaf and leader growth (Cornelius and Graham 1958; Hyder and Sneva 1956, 1962; Hyder et al. 1962). Percent control usually decreases when big sagebrush is sprayed in summer (Sosebee 1983); however, Evans and Young (1977) reported 2,4-D to be equally effective in the intermountain region when applied in fall compared to spring.

According to Hyder (1954), big sagebrush mortality is enhanced by applying phenoxy herbicides at determined growth stages and when soil moisture is not limiting. Hormay et al. (1962) reported poor herbicide control on big sagebrush growing on dry sites, but

\footnotetext{
Authors are professor and research specialist, Department of Animal and Range Sciences, New Mexico State University, Las Cruces 88003; and county Extension agent, Battle Mountain, Nev. 89820 . At the time of the research, Anderson and Balliette were research assistants, Department of Animal and Range Sciences, New Mexico State University.

Appreciation is expressed to Norman Wolf, San Juan County Extension agent, to Dupont Chemical Company for herbicide, and to the Farmington and Taos Resource Area BLM for their assistance in the research. Financial support was provided by the New Mexico Range Improvement Task Force, the New Mexico Agricultural Experiment Station, and the Integrated Pest Management Special Grants Program.

Journal Article 1572 of the New Mexico Agr. Exp. Sta., Las Cruces 88003-0003.

Manuscript accepted 1 May 1991.
}

greater than $90 \%$ control when plants grew on relatively wet sites. Precipitation in northern New Mexico averages less than $6.5 \mathrm{~cm}$ from January to June, and this limits big sagebrush shoot growth (McDaniel and Balliette 1986). Application of phenoxy-like herbicides in this region, including 2,4-D, dicamba (3,6-dichloro-2methoxybenzoic acid), triclopyr ([(3,5,6-trichloro-2-pyridynyl)oxy] acetic acid) and clopyralid (3,6-dichloro-2-pyridinecarboxylic acid) applied as sprays during May, June, or July have been largely ineffective, except at high use rates (Duncan and McDaniel 1988, Whisenant 1987). Most big sagebrush chemically controlled in northern New Mexico is treated with tebuthiuron ( $\mathrm{N}-[5-(1,1-$ dimethylethyl)-1,3,4-thiadiazol-2-yl]-N,N'-dimethylurea). Tebuthiuron, which is applied to the soil and transported through the roots, can be applied irrespective of the growth stage of big sagebrush, killing about $90 \%$ of the shrubs at rates of $0.6 \mathrm{~kg}$ ai/ ha or higher (McDaniel and Balliette 1986).

Recent research has been directed towards use of metsulfuron (2-[I[[(4-methoxy-6-methyl-1,3,5-triazin-2-yl)amino]carbonyl]amino]sulfonyl]benzoic acid) for control of various rangeland weeds including multiflora rose (Rosa multiflora Wendl.) (Derr 1989), spotted knapweed (Centaurea maculosa Lam.) (Lass and Callihan 1989), Canada thistle (Cirsium arvense [L.] Scop.) (McKone 1989), and broom snakeweed (Gutierrezia sarothrae [Pursh.] Britt. and Rusby) (McDaniel and Duncan 1987). Metsulfuron is a member of the sulfonylurea group, which are potent inhibitors of plant growth at low application rates. Unlike 2,4-D, which induces a massive cellular proliferation of photosynthates in the meristematic tissue of plants (Anderson 1983), metsulfuron inhibits enzymes needed to produce essential amino acids valine and isoleucine. Under ideal conditions, metsulfuron applications result in rapid cessation of cellular growth and eventual plant death (Beyer et al. 1988). Because the mode of action of metsulfuron is different from that of 2,4-D, many growth and environmental conditions prescribed when spraying 2,4-D for big sagebrush control may not be applicable for metsulfuron treatments. The primary object of this study was to compare the effectiveness of metsulfuron and 2,4-D, applied at various rates, for control of Wyoming big sagebrush in northern New Mexico. Changes in herbaceous vegetation after treatments were also determined.

\section{Materials and Methods}

An experiment to evaluate Wyoming big sagebrush control with metsulfuron and 2,4-D was established in 1982 and 1983 near Bloomfield and Questa, New Mexico. Both sites supported dense sagebrush stands with greater than $18 \%$ canopy cover and 13,000 plants/ha. The Bloomfield site was established on a deep and well drained Doak sandy loam (Typic Haplargid). Five composite soil samples collected to $10-\mathrm{cm}$ depth in the immediate area of the experiment contained $86 \%$ sand, $12 \%$ silt and $2 \%$ clay, with $1.6 \%$ organic matter and a pH of 7.0. Slope at the site was 1 to $3 \%$ and elevation was $1,600 \mathrm{~m}$. Prominent grasses included blue grama (Bouteloua gracilis [H.B.K.] Lag. ex Steud.), galleta (Hilaria jamesii [Torr.] Benth), sand dropseed (Sporobolus cryptandrus [Torr.] Gray), and squirreltail (Elymus longifolius (Smith) Gould). The Questa site was established on a Fernando loam soil (Ustollic Haplargid) containing $65 \%$ sand, $26 \%$ silt and $9 \%$ clay with $1.3 \%$ 
organic matter and a pH of 6.5. Average slope was 1 to $3 \%$ and elevation was $2,150 \mathrm{~m}$. Common grasses included western wheatgrass (Agropyron smithii Rydb.), galleta, and blue grama.

Initial treatments were applied to Wyoming big sagebrush during the period of primary shoot growth on 19 May, 10 June, and 30 June 1982. Treatments included a $60 \%$ active ingredient, dry, flowable formulation of metsulfuron at $0.14,0.28$, and $0.56 \mathrm{~kg}$ ai/ ha; and the butoxyethyl ester and alkanolamine salt of 2,4-D at $2.2 \mathrm{~kg} \mathrm{ae} / \mathrm{ha}$. Treatments were reapplied to a nearby set of plots on 8 June 1983, except metsulfuron rates were reduced to $0.035,0.07$, and $0.14 \mathrm{~kg} / \mathrm{ha}$, and only 2,4-D ester was applied at $2.2 \mathrm{~kg} / \mathrm{ha}$. Precipitation was above normal during both years of herbicide applications at Bloomfield (Table 1) and Questa (data not shown).

\section{Table 1. Precipitation recorded at Otis, New Mexico, near the Bloomfield site between 1982 to 1988.}

\begin{tabular}{lrrrrrrrr}
\hline \hline & \multirow{2}{*}{$\begin{array}{c}\text { 50-year } \\
\text { Monerage }\end{array}$} & \multicolumn{7}{c}{ Precipitation by year } \\
\cline { 2 - 9 } & 1982 & 1983 & 1984 & 1985 & 1986 & 1987 & 1988 \\
\cline { 2 - 9 } January & 15 & 11 & 41 & 6 & 22 & 0 & 24 & 19 \\
February & 11 & 31 & 9 & 1 & 7 & 13 & 40 & 24 \\
March & 17 & 34 & 34 & 17 & 36 & 9 & 25 & 2 \\
April & 14 & 4 & 10 & 11 & 75 & 29 & 3 & 16 \\
May & 10 & 47 & 8 & 5 & 1 & 14 & 13 & 10 \\
June & 7 & 0 & 10 & 17 & 6 & 34 & 9 & 82 \\
July & 24 & 42 & 14 & 45 & 68 & 70 & 11 & 29 \\
August & 32 & 93 & 65 & 64 & 1 & 46 & 15 & 73 \\
September & 21 & 22 & 47 & 19 & 41 & 49 & 12 & 17 \\
October & 29 & 2 & 24 & 46 & 39 & 49 & 22 & 7 \\
November & 16 & 15 & 23 & 7 & 23 & 78 & 40 & 17 \\
December & 15 & 51 & 36 & 17 & 5 & 16 & 14 & 5 \\
\hline Total & 211 & 352 & 321 & 255 & 324 & 407 & 228 & 301 \\
\hline
\end{tabular}

Herbicides were applied with a trailer-mounted sprayer $(6.4 \mathrm{~m}$ boom) delivering $1401 /$ ha total volume. The 2,4-D formulations were mixed in water or in a water-plus-diesel mixture $(1: 9 \mathrm{v} / \mathrm{v})$. Metsulfuron was mixed in water only. A $0.5 \%(v / v)$ surfactant (trimethylnonyl-polyethoxy-ethanol) was added to all mixtures. Plots were 19.2 by $67 \mathrm{~m}$ and replicated in a randomized complete block design. Wyoming big sagebrush mortality was determined by counting live and dead plants before and 3 growing seasons (about 28 months) after treatment. Counts were made within two $1-\mathrm{m}$ by $35-\mathrm{m}$ belt transects located diagonally across each plot. Wyoming big sagebrush canopy cover was also measured before and 3 growing seasons after treatment along two 35 -m line intercept transects placed in each plot (Hutchings and Pase 1963).

Grass and forb yield was determined from 1982 treatments by harvesting species in 2,4-D ester, metsulfuron, and untreated plots. Herbage data was collected in August 1982, 1983, 1985, and 1989 at the Bloomfield site, and all dates except 1989 at Questa because this area was disturbed. Data were obtained by clipping species within 10 randomly located $0.25-\mathrm{m}^{2}$ quadrats in each plot. Cattle grazed both study sites lightly in winter, but neither area was grazed during the summer growing season throughout the study.

A second experiment was established near earlier treatments on the Bloomfield site to evaluate spring and fall applications for control using metsulfuron and 2,4-D in 1986 and 1987. Treatments consisted of 2,4-D ester at $2.2 \mathrm{~kg} / \mathrm{ha}$, metsulfuron at $0.07 \mathrm{~kg} / \mathrm{ha}$, and a mixture of $2,4-\mathrm{D}$ at $1.1 \mathrm{~kg} / \mathrm{ha}$ and metsulfuron at 0.035 $\mathrm{kg} / \mathrm{ha}$. Treatments were replicated 3 times and applied to the same sized plots, and in the same manner as previously described, during Wyoming big sagebrush primary shoot growth (14 May, 13 June 1986; 25 April, 11 May, and 13 June 1987) or during the flowering and fruiting growth stages (23 September, 18 October 1986, 19 September, and 17 October 1987). Wyoming big sagebrush mortal- ity and canopy reduction data was collected for all treatments using the same procedures described in the previous experiment. Within untreated (control) plots, 30 Wyoming big sagebrush plants were randomly selected for monthly shoot elongation measurements beginning in mid-March and continuing to midNovember 1986. Measurements were repeated for the same period in 1987 as an index to predict susceptibility of Wyoming big sagebrush to the herbicides. Four terminal shoots on each plant were permanently marked at a prominent node with color-coded wire, at or near the 4 cardinal directions on the outer canopy perimeter. Measurements of current year growth were taken from the marked node to the apex of the shoot. As flowering shoots developed in mid-summer, they were marked for separate measurement from vegetative shoots. On each sample date, sagebrush phenology was also recorded using a numerical system described by DePuit and Caldwell (1973). Precipitation on the study area was nearly twice the 50-year average in 1986, although winter rainfall (Dec. 1985-March 1986) previous to herbicide application was slightly below normal (Table 1). Precipitation was near the longtime average in 1987 , but fall-winter precipitation was above average.

A third experiment to evaluate additional rates of metsulfuron applied in spring or fall was established in mid-May 1987 and 1988, and early October 1987 and 1988 at the Bloomfield site. Treatments included metsulfuron at $0.0175,0.035,0.07,0.14,0.28$, and $0.56 \mathrm{~kg} / \mathrm{ha}$. Metsufuron was applied with a pressurized $\mathrm{CO}_{2}$ backpack sprayer for product explusion at 20 psi through a $2.5-\mathrm{m}$ boom. Walking speed was timed to assure uniform application of treatments. Plot size was $9-\mathrm{m}$ by $15-\mathrm{m}$ with 3 replications. Wyoming big sagebrush mortality was determined in each plot in August 1990 using two $1-\mathrm{m}$ by $15-\mathrm{m}$ belt transects. Mortality results from this experiment were pooled with similar data acquired from other metsulfuron treatments applied at the Bloomfield site between 1982 and 1988 to show the relative effectiveness of the herbicide by rate and season applied. Metsulfuron treatments applied during this period in April, May, or June were combined as a spring data set, whereas treatments applied in September or October were combined as a fall data set. Separate regression analyses were conducted on spring and fall data sets to relate metsulfuron rates to Wyoming big sagebrush mortality.

\section{Statistical Analysis}

Apparent sagebrush mortality and canopy reduction means $(\bar{x})$ for each experiment were transformed to the $\operatorname{arc} \sin \sqrt{x}$, and subjected to analysis of variance using the protected LSD technique (Statistical Analysis System 1982). Herbage yield data did not differ significantly $(P>0.05)$ by date of herbicide application, so values were pooled within years by treatment for analysis.

\section{Results and Discussion}

\section{Wyoming Big Sagebrush Control}

Sprays of 2,4-D amine mixed in water or a diesel oil:water emulsion were less efficacious than 2,4-D ester, killing less than $15 \%$ of the Wyoming big sagebrush when applied in 1982 near Bloomfield and Questa, N.M. (data not shown). This agrees with numerous studies that have reported the advantage of ester formulations of 2,4-D compared to amines for sagebrush control (Evans et al. 1979). Also, no differences were found when 2,4-D ester was mixed in a 1:9 diesel oil:water carrier or mixed in water only for Wyoming big sagebrush control. Use of a diesel oil:water emulsion is usually recommended to reduce evaporation potential when aerially applying 2,4-D, and to increase herbicide absorption (Scifres 1980). As expected, 2,4-D ester killed a higher percentage of Wyoming big sagebrush when applied earlier in spring than later in the season (Table 2). However, Wyoming big sagebrush mortality 
Table 2. Wyoming big sagebrush mortality and canopy reduction 3 years after ground application of herbicides in May-June, 1982 near Bloomfield and Questa, New Mexico.

\begin{tabular}{|c|c|c|c|c|c|c|c|}
\hline \multirow[b]{3}{*}{ Herhicide } & \multirow[b]{3}{*}{ Rate! } & \multicolumn{6}{|c|}{ Sagebrush response by application dat } \\
\hline & & \multicolumn{3}{|c|}{ Bloomfield } & \multicolumn{3}{|c|}{ Questa } \\
\hline & & $5 / 19$ & $6 / 10$ & $6 / 29$ & $5 / 18$ & $6 / 11$ & $6 / 30$ \\
\hline & $(\mathrm{kg} / \mathrm{ha})$ & \multicolumn{6}{|c|}{ (\% mortality $)^{2}$} \\
\hline $2,4-\mathrm{D}$ ester ${ }^{3}$ & 2.2 & 37 & 14 & 18 & 38 & 25 & 27 \\
\hline Metsulfuron & 0.14 & 48 & 52 & 54 & 70 & 64 & 58 \\
\hline Metsulfuron & 0.28 & 83 & 73 & 70 & 69 & 78 & 87 \\
\hline \multirow[t]{2}{*}{ Metsulfuron } & 0.56 & 90 & 90 & 90 & 87 & 90 & 77 \\
\hline & & \multicolumn{6}{|c|}{$-(\%$ canopy reduction $)$} \\
\hline 2,4-D ester & 2.2 & 28 & 8 & 15 & 25 & 13 & 21 \\
\hline Metsulfuron & 0.14 & 48 & 35 & 35 & 80 & 67 & 45 \\
\hline Metsulfuron & 0.28 & 90 & 80 & 73 & 67 & 94 & 90 \\
\hline Metsulfuron & 0.56 & 98 & 94 & 98 & 94 & 90 & 80 \\
\hline
\end{tabular}

'Expressed as acid equivalent for 2,4-D; and as active ingredient for metsulfuron. ${ }^{2}$ LSD $(0.05)$ values for comparing sagebrush mortality and canopy reduction values are 14 and 16 , respectively.

${ }^{3}$ No significant difference was found between mixing 2,4-D ester in a 1:9 diesel oil water carrier or mixing the herbicide in water only, thus, data from these treatments were pooled for analyses.

never exceeded $38 \%$ on any spray date at either location, and these percentages are low in comparison to those usually reported when the plant is sprayed in more mesic environments (Evans and Young 1977).

Wyoming big sagebrush leaves had mostly shed 4 months after 2,4-D applications, but were only discolored and remained on shrubs sprayed with metsulfuron (data not shown). After 1 year, about 75 to $95 \%$ of the leaves were shed from plants sprayed with metsulfuron, but some green tissue remained on most plants. Wyoming big sagebrush mortality 3 years after applying metsulfuron at $0.14 \mathrm{~kg}$ / ha was greater across spray dates at the Questa location (64\%) compared to Bloomfield (51\%) (Table 2). Annual rainfall is normally $10 \mathrm{~cm}$ higher near the Questa site compared to Bloomfield and, although soil moisture was high at both locations when plants were sprayed, we suspect environmental conditions were more favorable for Wyoming big sagebrush growth near Questa. Metsulfuron was equally efficacious at higher rates of application across locations and spray dates, averaging 77 and $87 \%$ at 0.28 and $0.56 \mathrm{~kg} /$ ha, respectively. Wyoming big sagebrush mortality after applying lower rates of metsulfuron on 8 June 1983 was comparable across sites, and averaged 31,44 , and $60 \%$ at rates of $0.035,0.07$, and $0.14 \mathrm{~kg} / \mathrm{ha}$, respectively. Canopy reduction 3 growing seasons after 1983 treatments averaged 35,59 , and $78 \%$, respectively. Mortality with 2,4-D ester averaged 35\% and canopy reduction averaged $33 \%$.

Typically, Wyoming big sagebrush is senescent from early November until bud break in late March to early April in northern New Mexico. Spring shoot growth follows bud break by 2 to 4 weeks in late April and continues until mid-September. Flowering and fruiting occurs mostly in October and November. Phenophasic beginnings were generally later (by 2 to 4 weeks) in 1986 than those observed in 1987 (Anderson 1989). DePuit and Caldwell (1973) reported main phenophasic beginnings to be about a month later on Wyoming big sagebrush in northern Utah compared to plants we examined in this study. Growth of Wyoming big sagebrush terminal shoots in 1986 was greatest between 15 April and 15 May (Fig. 1). Mean shoot length for this month averaged about $11 \mathrm{~mm}$, with a range from 0 to $72 \mathrm{~mm}$. Zero was the mode and the median was $7 \mathrm{~mm}$. This large variation was typical for all measurement periods because terminal shoot growth within and between plants was highly erratic. About $20 \%$ of marked shoots exhibited no growth during the entire year. Shoot growth was

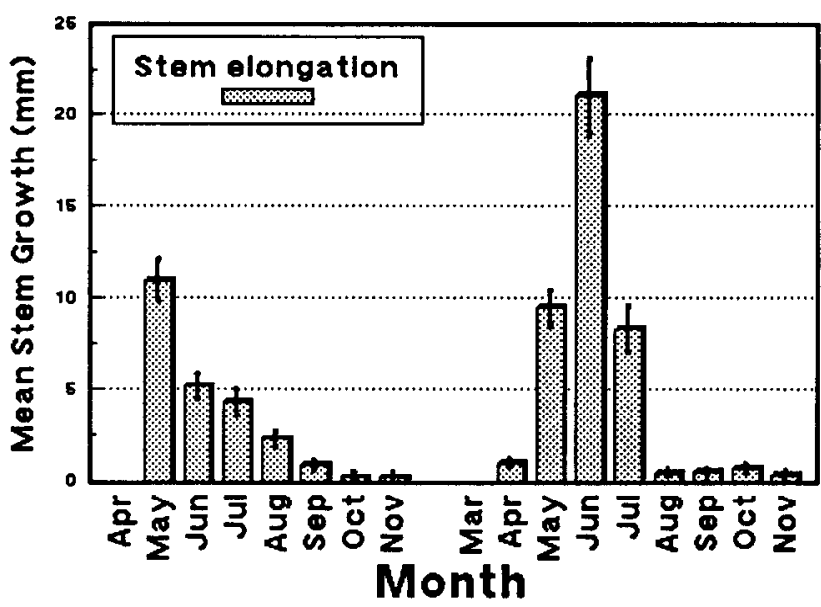

Fig. 1. Mean monthly growth increment and standard error measured on 120 Wyoming big sagebrush shoots in 1986 and 1987 at the Bloomfield site.

above-average on some plants, but no growth was observed on other shoots on the same plant. Lack of uniform shoot growth was probably responsible for the poor Wyoming big sagebrush control (11\% average mortality) by $2,4-\mathrm{D}$ ester at $2.2 \mathrm{~kg} / \mathrm{ha}$ in 1986 (Table 3). Activity of metsulfuron at $0.035 \mathrm{~kg} /$ ha was also poor when applied in May and June (23\% average mortality), but control was greater when applied in September and October (55\% average mortality).

Table 3. Wyoming big sagebrush mortality and canopy reduction in August 1990 following application of herbicides in 1986 and 1987 near Bloomfield, New Mexico.

\begin{tabular}{|c|c|c|c|c|c|c|c|}
\hline \multirow[b]{2}{*}{ Herbicide } & \multirow[b]{2}{*}{ Rate } & \multirow[b]{2}{*}{ Year } & \multicolumn{5}{|c|}{$\begin{array}{c}\text { Sagebrush response by application } \\
\text { date }\end{array}$} \\
\hline & & & April & May & June & Sept & Oct \\
\hline 2,4-D ester & $\begin{array}{l}(\mathrm{kg} / \mathrm{ha}) \\
2.2\end{array}$ & $\begin{array}{l}1986 \\
1987\end{array}$ & $\frac{-1 \%}{68}$ & $\begin{array}{c}\text { nortal } \\
13 \\
45\end{array}$ & $\begin{array}{r}\text { ty)--. } \\
10 \\
25\end{array}$ & $\begin{array}{l}13 \\
13\end{array}$ & $\begin{array}{r}7 \\
46\end{array}$ \\
\hline Metsulfuron & 0.035 & $\begin{array}{l}1986 \\
1987\end{array}$ & $\overline{26}$ & $\begin{array}{l}25 \\
27\end{array}$ & $\begin{array}{l}22 \\
17\end{array}$ & $\begin{array}{l}57 \\
63\end{array}$ & $\begin{array}{l}53 \\
63\end{array}$ \\
\hline $\begin{array}{l}\text { 2,4-D + } \\
\text { Metsulfuron }\end{array}$ & $\begin{array}{l}1.12+ \\
0.0175\end{array}$ & $\begin{array}{l}1986 \\
1987\end{array}$ & $\overline{55}$ & $\begin{array}{l}18 \\
48\end{array}$ & $\begin{array}{l}15 \\
17\end{array}$ & $\begin{array}{l}33 \\
67\end{array}$ & $\begin{array}{l}48 \\
74\end{array}$ \\
\hline 2,4-D ester & 2.2 & $\begin{array}{l}1986 \\
1987\end{array}$ & $\begin{array}{c}\% \text { cano } \\
- \\
65\end{array}$ & $\begin{array}{l}\text { py red } \\
18 \\
48\end{array}$ & $\begin{array}{c}\text { uction) } \\
17 \\
17\end{array}$ & $\begin{array}{l}25 \\
10\end{array}$ & $\begin{array}{l}12 \\
45\end{array}$ \\
\hline Metsulfuron & 0.035 & $\begin{array}{l}1986 \\
1987\end{array}$ & $\overline{33}$ & $\begin{array}{l}37 \\
32\end{array}$ & $\begin{array}{l}32 \\
20\end{array}$ & $\begin{array}{l}72 \\
62\end{array}$ & $\begin{array}{l}70 \\
73\end{array}$ \\
\hline $\begin{array}{l}\text { 2,4-D + } \\
\text { Metsulfuron }\end{array}$ & $\begin{array}{l}1.12+ \\
0.0175\end{array}$ & $\begin{array}{l}1986 \\
1987\end{array}$ & $\overline{48}$ & $\begin{array}{l}28 \\
52\end{array}$ & $\begin{array}{l}23 \\
13\end{array}$ & $\begin{array}{l}48 \\
60\end{array}$ & $\begin{array}{l}62 \\
85\end{array}$ \\
\hline
\end{tabular}

'LSD (0.05) values for comparing sagebrush mortality and canopy reduction are 25 and 27 , respectively.

Terminal shoot measurements were again highly variable in 1987, except that average cumulative growth was greater than that observed in 1986 (43.3 compared to $23.9 \mathrm{~mm}$, respectively) (Fig. 1). Growth measurements included vegetative shoots and flowering stalks, which usually could not be distinguished until mid-July or August. Mean growth of shoots on which flowering later occurred was nearly 4 times greater than that of shoots, which did not produce flowers in either year (data not shown). A higher percentage of Wyoming big sagebrush was killed or defoliated in 1987 when 2,4-D was applied on early or late application dates (April, May, and October) compared to dates near the middle of the growing season (June and September) (Table 3). Greater effective- 
ness of 2,4-D for control of sagebrush in spring and fall, compared to summer months, agrees with other studies by Hyder (1954) and Evans et al. (1979). As was observed in 1986, metsulfuron applied in 1987 killed a higher percentage of Wyoming big sagebrush during later application dates (average $59 \%$ mortality for September and October), than for earlier dates (average $23 \%$ mortality for April, May, and June). McDaniel and Duncan (1987) reported a similar seasonal difference in the effectiveness of metsulfuron for control of broom snakeweed. Treatments that included metsulfuron at $0.0175 \mathrm{~kg}$ / ha plus 2,4-D at $1.1 \mathrm{~kg} /$ ha provided comparable Wyoming big sagebrush control to $2,4-\mathrm{D}$ alone at $2.2 \mathrm{~kg} / \mathrm{ha}$ in April and May, and to metsulfuron alone at $0.035 \mathrm{~kg} / \mathrm{ha}$ in September and October. These data suggest synergism may exist between these 2 herbicides for Wyoming big sagebrush control but the optimum combination rates are unknown.

Metsulfuron applied at various rates in 1987 and 1988 further substantiated that the herbicide is more efficacious for Wyoming big sagebrush when applied in fall compared to spring (Table 4).

Table 4. Mortality of Wyoming big sagebrush following applications of metsulfuron in May and October 1987 and 1988 near Bloomfield, New Mexico.

\begin{tabular}{lcc}
\hline \multirow{2}{*}{$\begin{array}{l}\text { Metsulfuron } \\
\text { rate }\end{array}$} & \multicolumn{2}{c}{ Sagebrush response by season of application } \\
\cline { 2 - 3 }$(\mathrm{kg} / \mathrm{ha})$ & Spring & Fall \\
0.0175 & $22^{\mathrm{e}}$ & $40^{\mathrm{d}}$ \\
0.0350 & $47^{\mathrm{d}}$ & $72^{\mathrm{c}}$ \\
0.07 & $70^{\mathrm{c}}$ & $88^{\mathrm{b}}$ \\
0.14 & $74^{\mathrm{c}}$ & $94^{\mathrm{ab}}$ \\
0.28 & $100^{\mathrm{a}}$ & $98^{\mathrm{a}}$ \\
0.56 & $90^{\mathrm{ab}}$ & $100^{\mathrm{a}}$ \\
\hline
\end{tabular}

'Means followed by a different letter are significantly different by LSD at the 0.05 level.

Metsulfuron was nearly twice as effective at lower rates when applied in the fall compared to spring. As expected, when data from all metsulfuron treatments applied at the Bloomfield location between 1982 to 1988 were combined into spring and fall data sets, Wyoming big sagebrush mortality increased as rates increased (Fig 2). Further research is needed to explain the physiological basis for the greater metsulfuron activity on Wyoming big sagebrush applied in fall compared to other times of the year.

\section{Forage Production}

Total herbaceous production, as end-of-season standing crop, was not significantly different in herbicide-treated plots compared to untreated rangeland the first growing season after application near Questa, but was 200 to $300 \%$ higher in sprayed areas near Bloomfield (Table 5). Total herbaceous standing crop usually

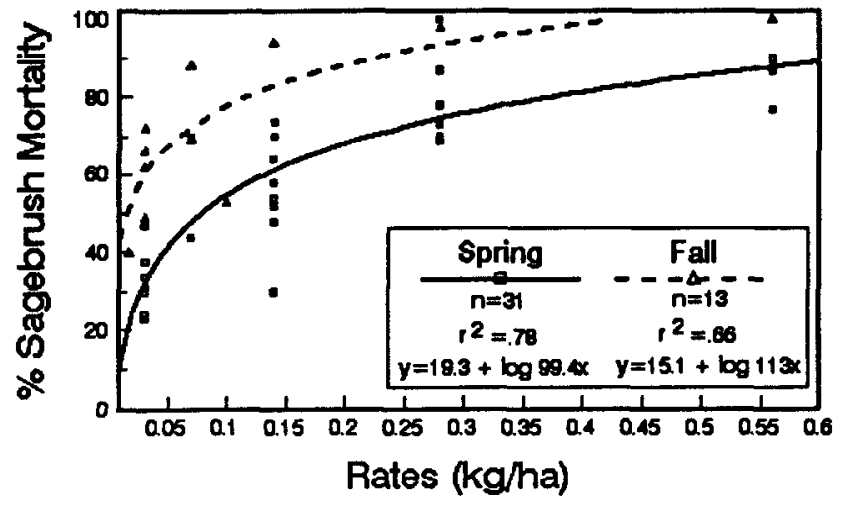

Fig. 2. Wyoming big sagebrush mortality following application of various rates of metsulfuron in spring (April, May, or June) and fall (September or October) near Bloomfield, New Mexico, 1982 to 1988.

increased on all treated plots, compared to untreated areas, at the Questa site after the second post-treatment growing season. In general, herbaceous yield in plots sprayed with 2,4-D and the 0.14 $\mathrm{kg} /$ ha rate of metsulfuron were equivalent. As expected, herbage yield was usually greater where a higher percentage of sagebrush was controlled by the 0.28 and $0.56 \mathrm{~kg} /$ ha rates of metsulfuron. Major differences among treatments were contributed by grasses, with galleta contributing about $65 \%$ of the total composition by weight at Bloomfield and western wheatgrass contributing about 85\% at Questa. Blue grama was the most important associated species at both sites. No evidence of damage to any herbaceous species was noted in either 2,4-D or metsulfuron treatments after the first growing season. Broadleaf species, primarily woolly plantain (Plantago patagonica Jacq.) and scarlet globemallow (Sphaeralcea coccinea [Nutt.] Rydb.), were equally evident in either treated or untreated plots, but comprised less than $1 \%$ of the total composition by weight at both sites (data not shown).

\section{Conclusions}

Big sagebrush is successfully controlled by 2,4-D and other phenoxy herbicides in the Great Basin, Columbia River, and the northern High Plains. However, because results are erratic, this practice has not been widely employed on the Colorado Plateau encompassing portions of Arizona, Utah, Colorado, and New Mexico (West 1978). Wyoming big sagebrush is reportedly susceptible to 2,4-D when soil moisture is available to promote at least 5 to $7 \mathrm{~cm}$ of new shoot growth before spraying phenoxy herbicides (Cornelius and Graham 1958). However, precipitation averages about $6.5 \mathrm{~cm}$ on the Colorado Plateau from January to June,

Table 5. Herbaceous standing crop in August 1982, 1983, 1985, and 1989 following herbicide applications to Wyoming big sagebrush in May-June 1982 near Bloomfield and Questa, New Mexico.

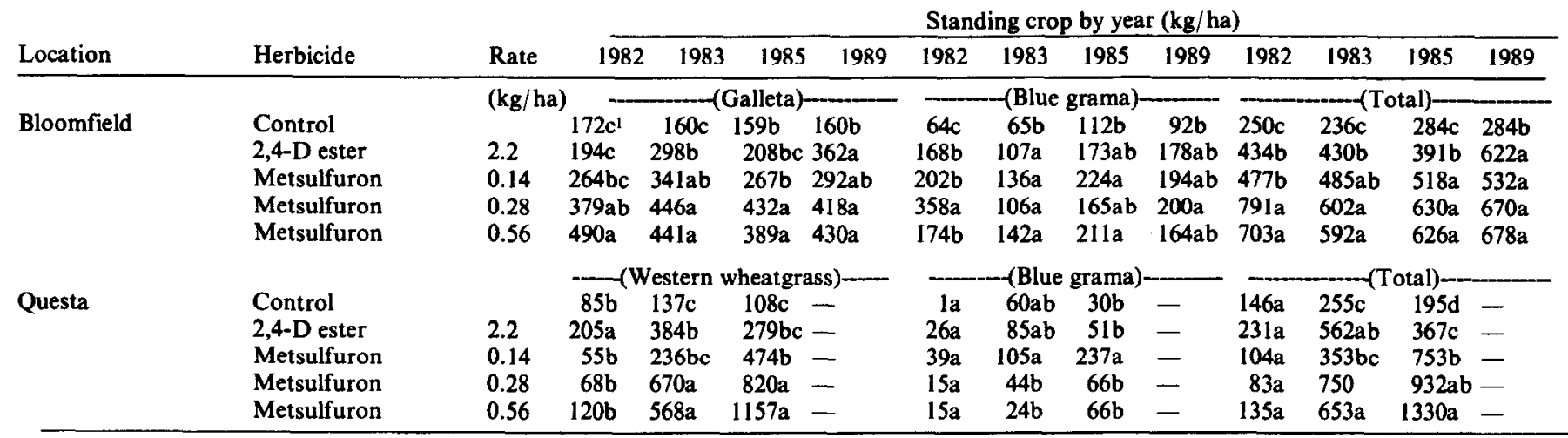

'Numbers in the same column and location followed by the same letter are not significantly different by LSD at the 0.05 level. 
which is probably not enough to promote adequate shoot growth in most years to insure effective Wyoming big sagebrush control. Our data suggest, even in years with above average winter-spring precipitation, terminal shoot growth is likely to average less than 5 $\mathrm{cm}$, and growth among stems is likely to be highly variable within and between plants.

Metsulfuron activity does not appear to be related to leaf or leader growth because Wyoming big sagebrush was more readily controlled by the herbicide when applied at comparable rates in fall compared to spring. Wyoming big sagebrush control averaged $65 \%$ when metsulfuron was fall-applied at $0.035 \mathrm{~kg} / \mathrm{ha}$, whereas mortality increased to $88 \%$ when metsulfuron was sprayed at 0.07 $\mathrm{kg} / \mathrm{ha}$. Metsulfuron plus 2,4-D worked reasonably well at the one combination rate examined. Some synergism may exist, but further research is needed to determine optimum metsulfuron plus 2,4-D combinations.

\section{Literature Cited}

Anderson, W.P. 1983. Weed science: Principles. West Publ. Co. St. Paul, Minn.

Anderson, D.L. 1989. Response of Wyoming big sagebrush to herbicide applications on the Colorado Plateau of New Mexico. Ph.D. Diss., New Mexico State Univ. Univ. Microfilms. Ann Arbor, Mich. (Diss. Abstr. SF 1999.A454).

Beyer, E.M., M.J. Duffy, J.V. Hay, and D.D. Schluester. 1988. Sulfonylurea herbicides. In: Herbicides: Chemistry, degradation and mode of action. Vol. 3, Marcel Dekker, Inc., N.Y.

Cornelius, D.R., and C.A. Graham. 1958. Sagebrush control with 2,4-D. J. Range Manage. 11:122-125.

DePuit, E.J., and M.M. Caldwell. 1973. Seasonal pattern of net photosynthesis of Artemisia tridentata. Amer. J. Bot. 60:426-435.

Derr, J.F. 1989. Multiflora rose (Rosa multiflora) control with metsulfuron. Weed Tech. 3:381-384.

Duncan, K., and K.C. McDaniel. 1988. Summary of range brush control research-demonstration trials in New Mexico. New Mexico Agr. Exp. St. RITF Rep. 27.

Elwell, H.M., and M.B. Cox. 1950. New methods of brush control for more grass. J. Range Manage. 3:46-51.
Evans, R.A., and J.A. Young. 1977. Weed control revegetation systems for big sagebrush downy brome rangelands. J. Range Manage. 30:331-336.

Evans, R.A., J.A. Young, and R.E. Eckert, Jr. 1979. Use of herbicides as a management tool, p. 110-116. In: Proc. of The sagebrush ecosystem: A symposium. Utah State Univ., Logan.

Hormay, A.L., F.J. Alberico, and P.B. Lord. 1962. Experiences wiih 2,4-D spraying on the Lassen National Forest. J. Range Manage. 15:325-328.

Hull, A.C., Jr., and W.T. Vaugh. 1951. Controlling big sagebrush with 2,4-D and other chemicals. J. Range Manage. 27:27-29.

Hutchings, S.S., and C.P. Pase. 1963. Measurement of plant cover-basal, crown, leaf area, p. 22-30. In: Range research methods: A Symposium. USDA Misc. Pub. 940.

Hyder, D.N. 1954. Spray to control big sagebrush. Ore. Agr. Exp. Sta. Bull. 538.

Hyder, D.N., and F.A. Sneva. 1956. Herbage response to sagebrush spraying. J. Range Manage. 9:34-38.

Hyder, D.N., and F.A. Sneva. 1962. Selective control of big sagebrush associated with bitterbrush. J. Range Manage. 15:211-215.

Hyder, D.N., F.A. Sneva, and V.H. Freed. 1962. Susceptibility of big sagebrush and green rabbitbrush to 2,4-D as related to certain environmental, phenological and physiological conditions. Weeds 10:288-295.

Lass, LW., and R.H. Callihan. 1989. Spotted knapweed control in pasture. In: Proc. West. Sec. of Weed Sci. 42:172-173.

McDaniel, K.C., and J.F. Balliette. 1986. Control of big sagebrush (Artemisia tridentata) with pelleted tebuthiuron. Weed. Sci. 34:276-280.

McDaniel, K.C., and K. Duncan. 1987. Broom snakeweed (Gutierrezia sarothrae) control with picloram and metsulfuron. Weed Sci. 35:837-841.

McKone, M.B. 1989. Canada thistle (Cirsium arvense) control with clopyralid + 2,4-D alone and tank mixed with metsulfuron. In: Proc. West. Soc. of Weed Sci. 42:271.

SAS. 1982. SAS users guide: Basics. SAS Institute, Cary, N.C.

Scifres, C.J. 1980. Brush management: Principles and practices for Texas and the Southwest. Texas A \& M Univ. Press, College Station.

Sosebee, R.E. 1983. Physiological, phenological and environmental considerations in brush and weed control. In: Proc. Brush Management Symposium, (ed. K.C. McDaniel and R.E. Sosebee), Albuquerque, N. Mex.

Vallentine, J.F. 1980. Range development and improvements, 2nd ed., Brigham Young Univ. Press, Provo, Utah.

West, N.E. 1978. Basic synecological relationships of sagebrush-dominated lands in the Great Basin and the Colorado Plateau. p. 33-41. In: Proc. of The sagebrush ecosystem: A symposium. Utah State Univ., Logan.

Whisenant, S.G. 1987. Selective control of mountain big sagebrush (Artemisia tridentata ssp. vaseyana) with clopyralid. Weed Sci. 35:120-123. 